\title{
Work Analysis And Autonomy - Socialisme ou Barbarie's Concept of Revolutionary Work Research*
}

\author{
by Andrea Gabler
}

Cornelius Castoriadis hardly fits the stereotype of the isolated thinker, who develops theories in private, far away from the world. When reading his stimulating texts, we should have in mind that they were written in a specific political context, as part of Castoriadis' own revolutionary activism. Until the mid-1960s the French group "Socialisme ou Barbarie" (hereafter: "SouB"; "SB" is used hereafter with reference to their journal with the same name) was Castoriadis' political background. His works from that period were the direct expression of the group's discussions and activities.

The following article deals with an example of Castoriadis' political-theoretical collaboration with SouB. After a short view at the Marxist context at that time (1.), follows the description of SouB's work analysis, its main concept, results and limitations (2.), from which unfolds directly Castoriadis' theory (3.). By way of conclusion I shall show some implications for today's discussions about work (4.).

\section{Which Marxist background?}

Marxism is the context of SouB's work analysis - and at the same time it is not.

SouB, deriving from French Trotskyism in 1949, was a Marxist group at least in the beginning, but developed an unusual perspective vis-à-vis Marx's theory.

SouB's Marxist assumption that people make their history themselves - to quote Marx, that the history is the history of class struggles - led to a revolutionary programme centred on self-activity and grassroots-activism.

But within dominating Marxism as it appeared at that time in forms of orthodox communism, Stalinist or social-democratic parties and unions, there was limited space for such ideas. Only some marginal Marxist movements, like the Dutch council communism, referred to the hidden Marxist tradition of "power to the people"and turned against Lenin's idea of an vanguard organisation leading the working masses. In France, where an orthodox "PCF-CGT-system" (Hastings-King 1998) dominated the left through the 1960s, SouB was part of a rather small radical left that was opposed to orthodox communism / Marxism. But like every Marxist, SouB referred to the working class and its historical mission to fight and overwhelm capitalism, because the working class was seen as the one and only agent of revolutionary change. And the realm of work was the place of class struggles, where the antagonism 
between capital and labour expressed itself directly.

In spite of these assumptions, traditional Marxism has a peculiar relationship to work. Work is in the centre, but it is not the subject for empirical research or theoretical considerations beyond the concepts of political economy - human labour or the value of labour - as pointed out Braverman, for example. Marx and Engels seemed to be more interested in laws of historical development and in work as an economic form than in the fate and ideas of this or that individual worker. The actual organisation of industrial work was not regarded as a place of social emancipation.

SouB, repelled by the perversions of Marxist theory and experiences, especially those of Stalinist bureaucracy, referred to an undogmatic interpretation of Marxism, focussing on all open and hidden forms of class struggle and aiming at councilcommunist objectives. Thus the group came to develop a new conception of the analysis of work.

\section{SouB's analysis of work}

Claude Lefort, co-founder of SouB, elaborated in his essay "L'éxperience prolétarienne" (1952) a programme for revolutionary work analysis. Claiming with Marx that the working class is more than a mere economic category, Lefort points out that the history of the proletariat means experience, and that this experience should be seen as progressing self-organisation. By thinking of class struggle as a pure expression of an objective economic process and the executor of laws of historical development, party-Marxism had become counterrevolutionary.

Therefore it was necessary to rethink revolutionary perspectives.

The objective analyses should be subordinated to concrete analyses, because not any conditions but men are revolutionary, Lefort says. The basic question is to know how people appropriate their situations and change them in a spontaneous way. Instead of analysing the situation and the development of the proletariat from the top down, one should try to reconstruct proletarian attitudes towards work and society from an insider perspective. Lefort claims that the culture of working people is a kind of special power to organise things and to adopt technical development. At least it is a kind of special attitude towards social relationships. It is the proletariat's special creativity and ability for social organisation appearing in everyday life.

The analysis of the everyday life has to be done by témoignages (Engl. testimonies), i.e. written reports on personal experiences. It is important, that working people should regard this writing as part of their own experience. This could be a way to intensify and reflect upon insights which were until now more felt and fragmentary. This kind of analysis should allow the authors, to think about their experiences themselves, Lefort says. An important point is - differing from traditional scientific methods - that workers should not only write but interpret their témoignages themselves. Ideally there should be no separation between subject and object of 
research. Though real limitations exist, we could imagine this as a process of merging the roles of subject and object and of increasing self-activity, ending in a condition of autonomy.[1]

Lefort refers to two examples of témoignages, [2] and suggests basic questions which the témoignages of SouB should deal with: How does the subject acquire work under modern industrial conditions? Are there specific social relations between workers? How do they see themselves in society? Are there expressions of collective experience, which could be a historical power? Is there really a progress in self-organisation and in which form does this progress appear?

As subjects of the témoignages, Lefort suggests: relations amongst worker, work and factory; relations to co-workers and other social groups in the production plant; social life outside the factory and knowledge of society's developments; and attitudes towards proletarian tradition and history. All these aspects should help to make the culture of struggles and of collective solidarity on the shop floor visible, being a possible starting point for revolutionary transformation. Lefort formulates a very demanding programme with a clear phenomenological approach. $[3] \mathrm{He}$ recognizes some problems and limitations of his approach, but calls upon writing, collecting and publishing témoignages nevertheless.

Following Lefort's demand, four members of SouB published impressing, partly long reports of their daily working life experiences in SB.

The first one was Georges Vivier (real name: Georges Dupont), co-founder of SouB, who was employed at Chausson bus factory. His témoignages, published between 1952 and 1955, describe work as a relationship of subordination and humiliation. 44 Class relations clearly define themselves in daily situations at work, e.g.: entering the factory every morning; the ceremony of getting hired / a contract of employment; the moment of getting paid; situations of monotony and adaption. Even the "unpolitical" worker is conscious of being always exploited and therefore it is important for him / her to reduce the degree of exploitation.

Social relations between workers and (lower) management are characterised as an "armed peace"; every change coming from the top (e.g. management's interventions, technical changes) risks to provoke open war. The relationship between workers themselves is described as conflictual, based on competition and limited by a system of professional and wage hierarchies. Solidarity among workers mostly is reduced to the team or working group.

Vivier, concerned with semi-skilled labour in automobile production, shows mighty tendencies of the Fordistic system to "inferiorise" and to "roboterise" semi-skilled workers - but even here rebellion against monotony and alienation at work exists appearing in various forms. 5$]$ Besides, there is the permanent feeling to wage war. Workers have to defend their living conditions inside work, and their discussion about work organisation is a kind of daily practice. They embody a kind of practical 
critique of the organisation of the production process.

Inside the factory as well as outside it, a strong desire for dignity and respect appears, as Vivier points out. Vivier's orientation at Lefort's question is obvious. He shows the ambivalence of a working day - the experience of being a cog in a superior system of exploitation and power, but the experience of individual and collective selfmanagement and resistance as well.

Another of SouB's co-founders, Philippe Guillaume (real name: Cyril de Beauplan), a former white collar worker, he became afterwards a semi-skilled worker at Renault-Billancourt. "The factory is exactly the opposite of freedom": that is the conclusion of his experience as a semi-skilled worker on piece-rate.66]

"Everything that gets in touch with the factory is as if it was contaminated. If you leave the factory you'll want something new, something your own, trash, you want movement, noise, violence (...)."[7] Guillaume describes a totalitarian factory system whose function is to produce human characters assimilated to factory work. [8] Factory absorbs people arranging them in human poles of execution and management comparable to the tense relation between anode and cathode.

Nearly absent is the promising reference on emancipatory potentials in proletarian self-organisation in the bureaucratic-capitalist production process. He focuses on the superior coercive character of employment contracts and the nearly perfect interaction of society's production and reproduction in an almost closed system. Max Weber's dictum of modern bureaucracy as the "iron cage of serfdom" is clearly visible; at least Fordistic mass workers seem to be the modern fellahs in a totalitarian factory order. And there are parallels to Marx's words of factory despotism. The innermost restlessness of work relations seems to come to a complete standstill. In modern production you do not find a coming out of freedom but, as Guillaume points out, the opposite. The totalitarianism of the factory goes hand-in-hand with the totalitarianism of society. The latter expresses himself as modern morals and consumer's world - an "air-conditioned nightmare" (Castoriadis) with generalised exploitation, heteronomy and "proletarianisation".

Henri Simon, another important member of SouB, was a white collar worker at an insurance company, Assecurances Générales Vie, and his témoignages from

1956 deal with the transformation of white collar work at that time. He describes non-simultaneous processes of rationalisation differing from department to department, as well as the increase in new forms of control and management strategies causing resistance, struggle and opposition even in the world of the seemingly conformist white collar worker. On the one side Simon sees a convergence towards the blue collar worker's class, the distress of traditional individual behaviours, and the raising of new class consciousness. On the other side the white collar worker's behaviour and consciousness remain ambivalent: hierarchies are not criticised automatically. Simon describes struggles on the shop floor as well as the 
other témoignages - "every working white collar worker is a struggling white collar worker"[9] -, but he also points out differences between blue and white collar milieus. At least similar developments to industrial work take place - with the same inherent contradictions. White collar workers, too, are reduced to the role of executers, their work gets more and more senseless and unsatisfying, and there are daily guerrilla battles on concrete arrangements of work organisation. Simon describes how the employee's spirit to invent little tricks reaches an unexpected level. Sometimes these struggles are sources of conscious critique, but often even the involved persons do not perceive them as extraordinary. In spite of the heterogeneous composition of white collar workers at that time, their ambivalent mentality and slowly progressing consciousness,

Simon writes on possibilities of autonomous organisation, especially the "Conseil", a successful organization of an independent, grass-root staff association. ${ }^{[10]}$

I shall conclude these short descriptions of exemplary témoignages with DanielMothé (real name: Jacques Gautrat), skilled worker at RenaultBillancourt at that time, he became an industrial sociologist in the Seventies. His témoignages published between 1953 and 1965 are the most extensive and continuing reports on work and self-organisation, as well as on factory politics and workers' consciousness, immigrant workers, young and old workers, workers and culture. ${ }^{[11]}$ In his essay "L'usine et gestion ouvrière" (1957) Mothé summarises his experiences on the shop floor focussing on germs of autonomy, stimulating Castoriadis' theory decisively. $[12]$

Mothé destroys the common picture of rational work organisation in modern capitalist factories. Nothing is left of this picture in reality. Mothé writes, that workers see "(...) something totally different. (...) on our level we can hardly talk about rationality; what we see is even the negotiation of any organised plan, in other words, something, what we call 'a pigsty'."[13]

Management's organisational schemes try everything to avoid communication and contact between workers while they are working. Mothé writes, that even shaking hands with a colleague means a violation of the "holy factory law": though the worker's collective exists in reality, the order of the factory tries to isolate individuals through a complex system of surveillance. Engineering draughtsmen, engineers, storekeepers, foremen, gaffers, transport workers, inspectors, super-inspectors, timekeepers, safety experts, union delegates: "All of them, including the cleaner sweeping our workplace, all of them are concerned with us, so that we have to do only one thing: to keep the machine running and not to care about the rest."[14] This system restricts the worker's initiative, variety of tasks, and responsibility more and more - for semi-skilled workers on the assembly line as well as for skilled workers, like Mothé himself.

The worker should not know anything about production processes and work organisation. He should stick blindly to the rules, produce automatically, care 
nothing about colleagues and their problems, and in case of doubt always ask his superiors and do nothing else. The workers should be ignorant, who are not allowed to know what they do every day.

But on the whole, it is clear; these Fordistic principles of bureaucratic management of production are in conflict with the real necessities of production.

Production only works thanks to the worker's initiatives that were not allowed to exist and that were obstructed by management systematically. Mothé mentions a lot of examples of such permanent divergences from the official plan.

Knowledge and ignorance, rationality and irrationality are not distributed as they should be, following the prevailing role descriptions. Workers overtake tasks adopting other qualifications. Semi-skilled workers do the work of skilled workers (without getting paid as such) - formal and official qualifications and professional hierarchy does not matter much in the face of production's necessities. To learn how to work, Mothé says, is only possible in a community of workers, where you can participate to your co-workers experience and techniques.

From the workers' refusal of being reduced to mere executors and obey to these irrational structures derives their informal self-organisation, which appears in different forms. Mothé reports on toolmakers who do not care about the rules, producing user-friendly tools instead of spending a lot of energy to fetch unsuitable tools from the depot. Workers themselves arrange their machines, overtake "expert" tasks to get on faster, and keep hidden depots themselves. It is a sort of constructive infringement of the rules, which workers think necessary and appropriate to solve problems at work and to keep the production running.

Following only the official rules of work organisation would lead to an immediate collapse of production - remember "work to rule" being a form of strike. "One more time we have short-circuited factory's organisation, but that's only the price for being able to work."[15]

The workers' self-management consists in gaining control over their own work and to cooperate tacitly with their colleagues. This kind of opposition exists on every level. It is required not only to compensate insufficient processes, but also to fight against working conditions, especially against timekeepers and production speed. Forms of collective socialisation, and of tacit moral counter-norms arise from this informal field. The pressure of the counter-moral prevents workers from adopting dominating norms too much, assuring and stabilising unity among them: if one talks too long to the gaffer, one risks being booed by co-workers. If one squeals openly, one could immediately leave for another department. Worker's counter-norms enable opposition and resistance.

Mothé describes this as a social separation between management and workers, between planning / controlling work and "real" work with no real cooperation 
between the two. Management has no access to the reality of production; its knowledge remains abstract and theoretical. But the pressure of this blind hierarchy paralyses the whole organisation and it is the main reason for chaos, inefficiency and the permanent crisis on the shop floor.

SouB's témoignages-project was not successful in the long run: it did not go as far as the group wanted for the main reason that only a few workers could be motivated to express themselves through writing. But some important results should be recorded:

SouB's témoignages as reports from the shop floor give insights from the inside.

All of them - at least nearly 400 pages of about 4500 pages in SB - are thick descriptions of the daily work life in French Fordism at a time when concrete experiences of work was at best a subject of American-inspired industrial sociology focussing on the aspect of socio-psychological deviation. SouB's project remains a unique source of information on the effects of implementation of Fordism in France ending up in the Sixties. They show the almighty bureaucratic rationalisation on different shop floors as well as the changes in working classes' behaviour and consciousness, the dissolving of proletarian milieus, processes of individualisation and changing values - the "silent revolution" (Inglehart 1977) -, the de-politicisation of the former revolutionary class and its integration in bourgeois society. The former figure of the proud producer becomes a confused, unhappy figure through technical change and social and organisational consequences - e.g. the change of old social milieus and new forms of training. Hence SouB's concept is fundamental for a counter-history of Fordism because of its insistence on the experience of daily work as a central point and because of its radical conception.

SouB's témoignages answer Lefort's question in a positive way: yes, there is a process of progressive experience of emancipation; yes, an informal autonomy of working people, their creativity and originality, can be found. The double life of the factory is described as interplay of heteronomy and autonomy. Workers are excluded from managing their work themselves and at the same time they have to be included to guarantee the running of the production process. Having exposed this simultaneity of exclusion and inclusion is one of the most important results of the témoignages. This simultaneous movement can be seen at all levels of the hierarchy, it even pervades persons, and it is the source of contradictory interests and contradictory behaviours in situations of conflict.

SouB saw these germs of tacit self-organisation as political potential for changing society. The group tried to support these germs focussing on a model of direct democracy through assemblies and councils which should liberate people from hierarchies and should install self-organisation at all levels, individual as well as collective, at work as well as in society at large.

SouB's témoignages and the group's own history describe processes of modernisation. The "self-modernisation" of SouB is linked directly to their 
observations. At the end of the group's revolutionary work research, revolution is an option not only for the until then "privileged" working class, but also for all movements seeking autonomy - especially the new movements like the women's liberation, the student's movement or the Civil rights movement in the USA). The later fundamental breach of Castoriadis with traditional Marxism at the end of the 1950 can be seen as a further result of this "self-modernisation".[16]

\section{Témoignages and Theory}

What makes the témoignages particularly interesting is their theorisation by Castoriadis. It raises them above similar attempts of participatory research or literary narrations. Castoriadis develops his ideas reflecting on these experiences and SouB's discussions of them. Above all, his three-piece essay "Sur le contenu du socialisme" [17] possesses a remarkable close nearly symbiotic relationship to the texts of Mothé. Castoriadis interprets the témoignages as empirical material and deconstructs the fiction of rationality, order and efficiency in capitalist enterprises. The Fordistic organisation of work is not only contradictory and bureaucratic - a point of view which is shared by many Marxists -, but it is bureaucratic because it requires the subject's participation and exclusion at the same time. The irrationality of this process is not only shown by waste (of materials, time and possibilities) or by "bureaucratic dysfunction", but through the permanence of this dichotomy, constantly kept alive because of economic expansion and technological upheaval. The crisis of the whole capitalist society follows the same logic. "It [the crisis] consists in the fact that the social organisation can attain the ends it sets for itself only by setting forth means that contradict these ends, by creating demands it cannot satisfy, by posing criteria it is incapable of applying, norms it is obliged to transgress." $[18]$ The simultaneity of inclusion and exclusion produces a double reality and an extremely conflictual society. So bureaucratisation finds expression on every level of society. At work it expresses itself through a bottom-up, everlasting resistance against the existing institution of work as such.[19]

Castoriadis continues - as seen above in the témoignages - in describing the contradiction between inclusion and exclusion also as the most important social source for the revolutionary project. This contradiction can be observed as an informal self-activity, the raising of self-consciousness and, at some times, as openly revolutionary situations. All these phenomena show that the conflict is not centred on quantities (e.g. of working hours or wages) but on qualities (e.g. on the content and organization of work). From here Castoriadis derives his concrete Utopia of autonomy at work and in society. Even later on, when SouB and Castoriadis were to analyse the social "integration" of the working class, Castoriadis would insist on the fundamental possibility of people to create autonomy and a radical transformation of society.

\section{Implications for today's world?}

The question arises at first: what to do with an old Fordistic concept from France in 
the Post-Fordistic, new global world? Let me conclude by mentioning briefly some ideas concerning the relevance of the témoignages for today's discussions and developments.

First of all, though there is a long and rich tradition of academic research and discussion about work under capitalism, its "inner" life often remains hidden or undetermined. SouB's témoignages reflect this subject-orientated life and provide not only historical information, but also hints vis-à-vis future research designs on life-world (Lebenswelt) and culture of work. I would argue that subject-orientated empirical analyses enrich our understanding of work; these "ethnographies" make "cultures of solidarity" (Fantasia 1989) visible and show situations of upheaval from the person's affected point of view. [20] The témoignages are one important example opening the "black box" of daily working life.

As the implementation of SouB's "empirical" results in today's research is problematic, it seems reasonable to focus on their abstract results. The simultaneous inclusion and exclusion, as seen in the témoignages and in Castoriadis' theory, is a subject, which professional researchers in industrial sociology did not recognize at that time though the "power of (bureaucratic) organisation" was indeed an important subject for them too. Although today's mainstream industrial sociology seems to be more busy with "the money" or "the market", problems of power, control, and the contradictions of organisation have not yet disappeared. So what about inclusion and exclusion in today's work, "modernised" in the last decades through changing organisation, new concepts of management, and the

"flexibilisation" of work and life? New management strategies like job enlargement, job enrichment and job rotation are forms of rationalisation as well as a kind of reaction to the worker's human critique of work organisation. The new work organisation is characterized by qualitative and quantitative flexibility and is described as a form of processing interactive rationality. Factory rationalises itself, production seems to be integrated and unified, and even controlling and leading functions are to be dissolved in the working process.

These features of a post-Fordistic organisation of work seem to dissolve former bureaucratic structures based on the antagonism of capital and labour. In this way SouB's critique of the bureaucratic-capitalist power seems to become pointless. Capitalism arrived to incorporate the "artistic critique" (Boltanski / Chiapello 2004) [21], the critique of bureaucratic heteronomy, hierarchy and alienation via offers of participation and strategies of flexibilisation. The academic discussion and research dealing with the new management strategies is a debate on "chances" and "risks": the positive chance to bring in creativity and to enlarge the individual's room for manoeuvre, opposite to the negative risk of the highly flexible employee who is submitted to the imperatives of exploitation in a subtler way, but even more extensively, and whose personal resources are to be used more efficiently. The new organisation of work is seen as a pendular movement, dominated sometimes by tendencies to heteronomy (organisation from the outside, rational power) and 
sometimes by tendencies to participation.[22] Opposing this perspective, SouB and Castoriadis pointed out that inclusion and exclusion are necessary, and both necessarily exist at the same time. That is why reality is ambiguous and contradictory. The view of a pendular movement between these poles risks underestimating this contradictory simultaneity, going through all phenomena and every person.

In generalising the subject of inclusion and exclusion it can be stated that modern society always remains Janus-headed. It is difficult, confusing, sometimes nearly impossible to separate the simultaneous movement of inclusion and exclusion existing at every level of society. It would be interesting to have further research in this perspective, e.g. on gender relations - including women and excluding them from real power in society at the same time - or on representative "democracy" - including people by elections and excluding them from real decision-making. From this point of view, it would be a promising project to go beyond social and political phenomena like apathy, loss of meaning, privatization etc.

Concerning the sphere of production, the new developments are to be expressed more unambiguously as "subaltern democray" (Coriat 1991) or "controlled autonomy" (Wolf 1999) and "managed participation" (Linhart 1986), all reflecting that relations of power at work are modernised, but not abolished.

And at that point the results of SouB are still valid: if there is no fundamental solution to the dilemma of exclusion and inclusion under capitalism, the structural crises of production will only be moved from one level to another. In each level, one is confronted with the same new-old limits, Castoriadis has highlighted.

${ }_{-}^{*}$ I wish to thank Frauke Geyken and Harald Wolf for their comments and all the participants to the symposium for the inspiring and warm discussions. All French translations are by me.

[1] Similar limitations may be found in "progressive" streams in the social sciences, also trying to solve this separation in their research, e.g. action research, feminist approaches or sets of "committed" research sympathetic to the researched.

[2] These examples are Albert 1952 and Romano / Stone 1947. Romano's report was first published in 1947 by the "Johnson-Forest-Tendency", SouB's American "sisterorganization", then translated by SouB and published in the first five issues of SB.

[3] Thanks to the influence of his teacher and friend Maurice Merleau-Ponty (Hastings-King 1998, pp. 175ff).

[4] See Vivier 1952, Vivier 1953, Vivier 1954A, Vivier 1954B and Vivier 1955. Vivier lost his life in the Fifties because of an accident. 
[5] E.g. as work for private matters. See for parallels in "real socialism": Haraszti 1977.

[6] See Guillaume 1960 and Guillaume 1960. The quotation is taken from Guillaume 1961, p. 83 .

[7] Guillaume 1961, p. 81.

[8] Guillaume is very near to Marx, who wrote that the function of the factory is not to produce goods but proletarians.

[9] Simon 1956, p. 31.

[10] See Simon 1956. Simon is near to council communism, focusing very much on the "serving" role of the political activist and on the spontaneous movement of the working class. In 1958 Simon left SouB with Lefort and others, but remained a political activist since.

[11] Most of his témoignages were published later as "Journal d'un ouvrier"(1959), which made SouB as well as Mothé himself known in the public and led to some struggles with French industrial sociology. In 1965 Mothé released "Militant chez Renault", another book on his shop floor experiences (see Mothé 1957).

[12] For the influence on Castoriadis of Mothé's témoignages see Hastings-King 1998.

[13] Mothé 1957, p. 78.

[14] Mothé 1957, p.84.

[15] Mothé 1957, p. 90.

[16] On the relationsship between Castoriadis and Marx see Ramsay 2007.

[17] Castoriadis 1955, Castoriadis 1957 and Castoriadis 1958.

[18] Castoriadis 1964/65, p. 170.

[19] This resistance wouldn't be revolutionary or 'progressive' in all cases. In a similar context the historian Alf Lüdtke gives an account of worker's „Eigen-Sinn" („Selfmind" in the sense of obstinacy), which also could take reactionary forms (see Lüdtke 1993).

[20] I can't deepen this point here. You'll find many examples in Anglo-American and French research which seem to be more open for a "cultural approach" to work and / or using participatory research methods. German researchers working with a "cultural approach" can be counted on one hand. 
[21] The authors classify Castoriadis and SouB as a part of their "artistic critique".

[22] See for example Ailou-Gouday / Kunda 2005 or Boltanski / Chiapello 2004.

\section{References}

Ailou-Gouday, Galit / Kunda, Gideon (2005): Managers, Markets, and Ideologies: Design and Devotion Revisited, in: Stephen Ackroyd et al. (eds.): The Oxford Handbook of Work and Organization, Oxford/New York, pp. 200-219.

Albert, Eric (1952): La vie dans une usine, in: Les Temps Modernes, 8. Jg., No. 81, pp. 95-130.

Braverman, Harry (1974): Labor and Monopoly Capital: the Degradation of Work in the 20th Century. New York.

Boltanski, Luc / Chiapello, Eve (2004): Der neue Geist des Kapitalismus, Konstanz.

Castoriadis, Cornelius (1955): On the Content of Socialism I, in: idem: Political and Social Writings, Vol. 1, Minneapolis 1988, pp. 290-309.

--- (1957): On the Content of Socialism II, in: idem: Political and Social Writings, Vol. 2, Minneapolis 1988, pp. 90-154.

--- (1958): On the Content of Socialism III, in: idem: Political and Social Writings, Vol. 2, Minneapolis 1993, pp. 155-192.

--- (1964/65): Marxism and Revolutionary Theory: Excerpts, in: David Ames Curtis (ed.): The Castoriadis Reader, Oxford 1997, pp.139-195.

Coriat, Benjamin (1991): Penser à l'envers, Paris.

Fantasia, Rick (1989): Cultures of Solidarity. Consciousness, Action, and Contemporary American Workers, Berkeley/Los Angeles/London.

Gabler, Andrea (2001): Die Despotie der Fabrik und der Vor-Schein der Freiheit. Von "Socialisme ou Barbarie" gesammelte Zeugnisse aus dem fordistischen Arbeitsalltag, in: Archiv für die Geschichte des Widerstandes und der Arbeit Nr. 16, Fernwald, pp. 349-378.

--- (2008): Arbeitsanalyse und Selbstbestimmung. Zur Bedeutung und Aktualität von "Socialisme ou Barbarie", Göttingen, accessible online at: http://webdoc.sub.gwdg.de/diss/2008/gabler/gabler.pdf 
Guillaume, Philippe (1960): Dix semaines en usine (I), in: SB 31, pp.33-50.

--- (1961): Dix semaines en usine (II), in: SB 32, pp.73-83.

Haraszti, Miklos (1977): A Worker in A Worker's State, Harmondsworth.

Hastings-King, Stephen (1998): Fordism And the Marxist Revolutionary Project: A History of Socialisme ou Barbarie, Part I, Dissertation Cornell University.

Inglehart, Ronald (1977): The Silent Revolution. Changing Values and Political s Among Western Politics, Princeton/New Jersey.

Lefort, Claude (1952): L'expérience prolétarienne, in: SB 11, pp. 1-19.

Linhart, Danièle (1986): Ein japanisches Modell à la française oder ein französisches Modell à la 'japonaise', in: Kißler, Leo: Toyotismus in Europa, Schlanke Produktion und Gruppenarbeit in der deutschen und französischen Automobilindustrie, Frankfurt/New York, pp. 265-279.

Lüdtke, Alf (1993): Eigen-Sinn. Fabrikalltag, Arbeitererfahrung und Politik vom Kaiserreich bis zum Faschismus, Hamburg.

Mothé, Daniel (1957): L'usine et la gestion ouvrière, in: SB 22, pp. 75-111.

--- (1959): Journal d'un ouvrier, Paris.

--- (1965): Militant chez Renault, Paris.

Ramsay, Anders (2007): Castoriadis's Critique of Marx and Marxism - in „Modern Capitalism and Revolution". Paper presented on the summer session of Network Group 8 of NSU at Wik / Sweden, July, 28th.

Romano, Paul / Stone, Ria (1947): The American Worker, New York.

Simon, Henri (1956): Une éxperience d'organization ouvrière: Le Conseil du Personnel des Assecurances Générales-Vie, in: SB 20, pp.1-57.

Vivier, Georges (1952): La vie en usine (I), in: SB 11, pp. 48-54.

--- (1953): La vie en usine (II), in: SB 12, pp. 31-47.

--- (1954A): La vie en usine (III), in: SB 14, pp. 51-61.

--- (1954B): La vie en usine (IV), in: SB 15-16, pp. 44-59. 
--- (1955): La vie en usine (V), in: SB 17, pp.49-60.

Wolf, Harald (1999): Arbeit und Autonomie. Ein Versuch über Widersprüche und Metamorphosen kapitalistischer Produktion, Münster.

Dr. Andrea Gabler is a sociologist. She completed her PhD on the work analysis of "Socialisme ou Barbarie" at Georg-August-Universität Göttingen (Germany) in 2006. She is teaching at the department of political sciences of Georg-AugustUniversität in Göttingen. Her main research interests are sociology of work, ethnography, political theory, feminist theory, and sociology of social movements. A revised version of her thesis is forthcoming under the following title: Antizipierte Autonomie. Zur Theorie und Praxis der Gruppe "Socialisme ou Barbarie“(19491967), Hannover 2008. E-mail:agabler@gwdg.de 